\title{
THE QUESTION OF NATIONAL AND REGIONAL IDENTITY ON THE EXAMPLE OF POLISH AND GERMAN INTERPRETATIONS OF GDAŃSK ARCHITECTURE IN THE $19^{\text {th }}$ AND $20^{\text {th }}$ CENTURIES
}

\begin{abstract}
The architectural heritage and the mode of its analysis and interpretation, specially in the perspective of national and regional question, can and often becomes the issue prone to manipulation. The attempts to define national and regional identity by means of cultural legacy have been accompanying the research into art and also the creation of modern architecture in the spirit of national Historicism already since the $19^{\text {th }}$ century. The architecture of Gdansk has for years been the subject of a heated debate of both German and Polish architects, historians of architecture, and conservators. In the recent years also politicians have joined in the debate, and so have writers. The paper analyses the issue of the relation of architectural forms and rhetorical formulas, namely the combination of architecture and specific contents treated as signs of local identity, as well as changeability and interpretational flexibility of those issues with regard to the needs of political circumstances (idioms versus interpretational variants, stereotypes, research myths, likings versus scholarly idiosyncrasies). Special attention will be paid to the Gdansk architecture of the $2^{\text {nd }}$ half of the $19^{\text {th }}$ century and its contemporary and later interpretations in the perspective of regional and national identification.
\end{abstract}

Keywords: architecture of the 19. and 20. centuries, national identification, Neo-Renaissance, Danzig, Gdanisk, history of architecture

The architectural heritage and the mode of its analysis and interpretation, specially in the perspective of national and regional question, can and often becomes the issue prone to manipulation. The attempts to define national and regional identity by means of cultural legacy have been accompanying the research into art and also the creation of modern architecture in the spirit of national Historicism already since the $19^{\text {th }}$ century. The place where the phenomena can be observed in a particularly acute way is Gdansk, a city of extremely complicated identity, multicultural structure, and a rich architectural output, the latter having been on a number of occasions a subject to national interpretations or over-interpretations. ${ }^{1}$

\footnotetext{
* Małgorzata Omilanowska, Institute of Art of the Polish Academy of Sciences - Warsaw, History of Art Dept. University of Gdansk; E-mail: malgorzata.omilanowska $@$ ispan.pl, Fax: +48-22-831-31-49
}

The major problem concerning Gdansk and interesting in the context of the topic of the present Symposium does not only touch on the very issues of national and local interpretation of the history of architecture of the city by art historian, but first of all the translation of those interpretations into architecture raised in the city in the $19^{\text {th }}$ and $20^{\text {th }}$ centuries by German architects until 1944 and the Polish ones after 1945, which in consequence means the translation of those interpretations into the processes of restoration, conservation, and reconstruction of Gdansk monuments.

Architectural heritage of the old Gdansk, this meaning the main sphere of interest of the researchers into medieval and early modern art and the architectural cityscape that it shaped was dominated by buildings raised during the period when Gdansk belonged to the Polish crown. Naturally, already during the Teutonic times: in the $13^{\text {th }}$ and $14^{\text {th }}$ centuries and in the first half of the $15^{\text {th }}$ century, a number of impor- 
tant lay and sacral edifices had already been built, yet many of them, e.g. the Town Hall of the main city in the course of time underwent substantial alterations or were added extensions significant for their external reception, such as a huge tower added onto the Marian Church. In effect, only one important symbol of the city, namely the Crane Gate, dating from the Teutonic period has, apart from churches, survived unaltered until the modern times.

The most attractive, and as the time has shown most important buildings in the perspective of the reception of Gdansk architecture in later centuries were either created or thoroughly altered in the second half of the $15^{\text {th }}$ century, throughout the $16^{\text {th }}$ century, and in the first half of the $17^{\text {th }}$ century. The buildings of the Great Armoury, the Green, High, and Golden Gates, the Old Town Hall, and the Court of the Brotherhood of St. George, as well as of the altered Main Town Hall and the Artus Court have become the icons of the city. The character of the city is also shaped by dozens of tenement houses of typical narrow facades crowned with gables and preceded by perrons. The profile of the city dominated by edifices from High Middle Ages, Renaissance, Mannerism, and Baroque was additionally consolidated by a construction stagnation which lasted through the $18^{\text {th }}$ century and the majority of the $19^{\text {th }}$ century.

Anyone at least rudimentarily familiar with the facts from the Polish-German relations finds it absolutely obvious that the artistic legacy of Gdansk was bound to turn to be almost from the very beginning of the research into it a sphere of controversy and extremely differentiated interpretations between the Polish and German art historians. For the German scholars Gdansk architecture constituted an integral part of the German cultural legacy, yet the Poles regarded the buildings from the period when the city belonged to the Polish-Lithuanian Commonwealth as a part of their own tradition, interwoven, whether we want it or not, with various influences resulting from a peculiar character of a multi-denominational, multi-lingual, and multi-cultural state.

The present is not an appropriate opportunity to discuss in detail the German and Polish state of research into the architecture of Gdansk. Let me remind, however, that the German research into Gdansk architecture as seen in the perspective of
German art was started really early. ${ }^{2}$ The best accomplished Gdansk buildings could be found already among the prints of Georg Möller's portfolio published in $1821,{ }^{3}$ whereas the publications from the $1850 \mathrm{~s}, 1860 \mathrm{~s}$, and $1870 \mathrm{~s}$, mainly by Wilhelm Lübke, consolidated in the general German awareness the image of Gdansk architecture of the Renaissance as one of the better examples of German architecture. ${ }^{+}$

Views of Polish scholars on the architecture of Gdansk (I do not deal here with some detailed topographic studies) began to appear at the beginning of the $20^{\text {th }}$ century. ${ }^{5}$ The researchers traced in it first of all Netherlandish and Italian influences, at times literally denying any connection that it may have had with German art. It is enough to mention in this respect controversies regarding the terminology with reference to the architecture of the $16^{\text {th }}$ and $17^{\text {th }}$ centuries. The Germans defined those buildings as raised in the style of German Renaissance and Baroque. The Poles, in turn, preferred the term Northern Renaissance and Mannerism, eagerly emphasizing the main feature of this architecture, namely its relations with Netherlandish architecture, sometimes even excessively promoting the concept of Netherlandism in the context of Gdansk. ${ }^{6}$

The $18^{\text {th }}$ century brought no essential alterations in Gdansk's townscape. After 1793, Gdansk was encompassed within the boundaries of Prussia, whereas during the Napoleonic wars it suffered enormous devastation, losing for some decades to come almost completely any economic importance, at the same time starting the period of stagnation which also affected the creation of new buildings. It was only once a new West Prussian Province had been formed post 1878, namely after the establishment of the German Empire, when Gdansk was elevated to the status of the capital of the province, that a new momentum in the development of the city was gained, the economic growth accelerated, and a stimulus formed for the expansion of the city and enriching it with new public buildings. Historicism of the second half of the $19^{\text {th }}$ century determined the choice of a style from the past for them. The decision was made to follow the German Neo-Renaissance, already popular in the architecture of many German towns.

In 1880-1887, several projects were implemented in Gdansk, these being first and fore- 


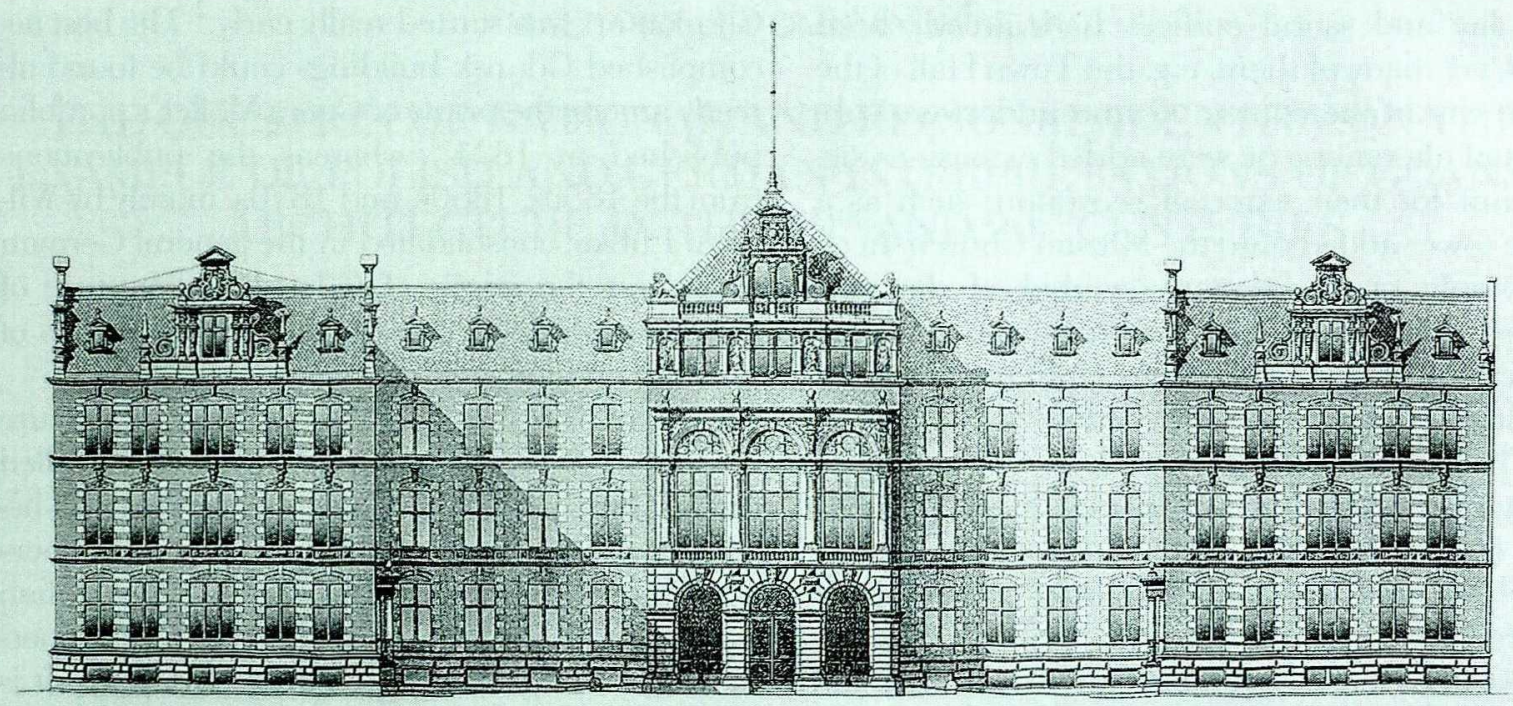

Fig. 1. Gdańsk, Supra-Presidency and Western Prussian Public Notary (Oberpräsidial- und Regierungsgebäude), Karl Friedrich Endell, 1879-1886, repr.: Zeitschrift für Bawwesen, 1889, BI. 1.

most the buildings of the Supra-Presidency and Western Prussian Public Notary (Oberpräsidialund Regierungsgebäude, Fig. 1) designed by the Berlin architect Karl Friedrich Endell and of the Governance of the Western Prussia Provinces (Landeshaus, Fig. 2) designed by the Berlin architectural company Ende \& Böckmann. Around

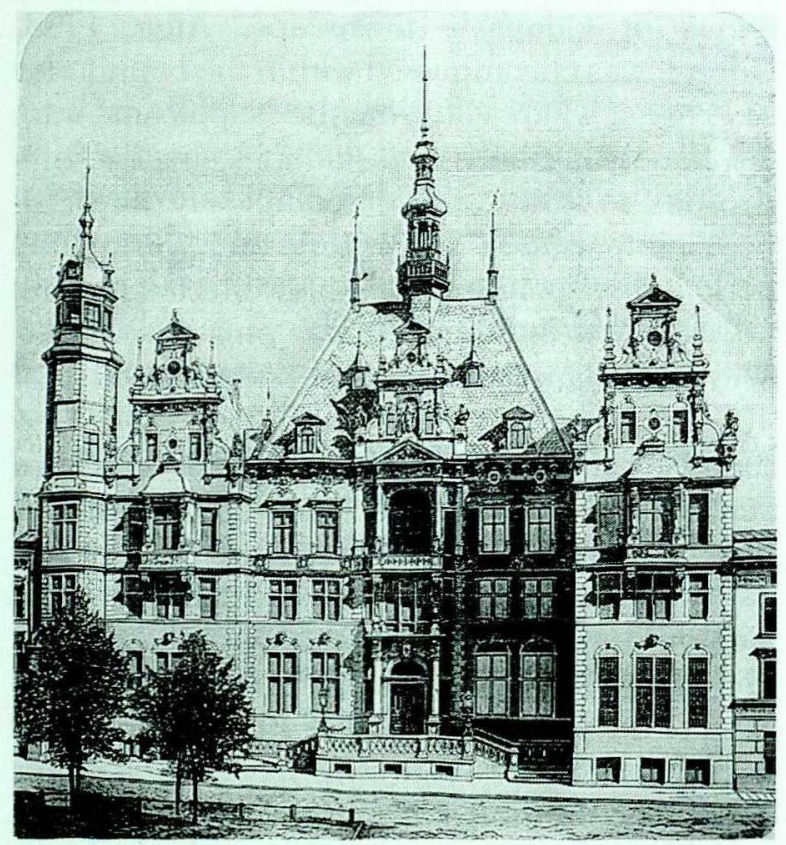

Fig. 2. Gdańsk, the Governance of the Western Prussia Provinces (Landeshaus der Provinz Westpreussen), Ende \& Böckmann, 1880-1884, repr.: Zentralblatt der Bauverwaltung, 1885, nr 1, p. 5. the same time the latter also raised two other important edifices in Gdansk: the Great Synagogue and the building of the Saving Bank (Sparkasse). In professional media in which all the designs were published it was emphasized that the buildings stylistically adhered to German Neo-Renaissance; additionally, on a specified wish of the then city's Oberbürgermeister Leopold von Winter, as is testified by source texts, a clear reference to the local architectural legacy was enhanced. ${ }^{8}$

In view of the research into the architecture of German Neo-Renaissance, which points to its strong national and bourgeois connotations, as well as its relations with the myth of the Hanseatic League, ${ }^{9}$ the choice of this very style for the new architecture of Gdansk - the capital of an Empire's province may be considered most just from the point of view of the city authorities' political ambitions, which was later testified by Gdansk's career. It allowed to enhance the fact that Gdansk belonged to the Empire, and at the same time signalled its local distinctness, it made reference to the bourgeois tradition of the town and referred directly to the times of the former grandeur of the city whose restoration was the dream of its inhabitants.

The second stage of the extension of Gdansk took place in the years 1895-1910, after the modern city fortifications had been pulled down. German Neo-Renaissance was already by that 


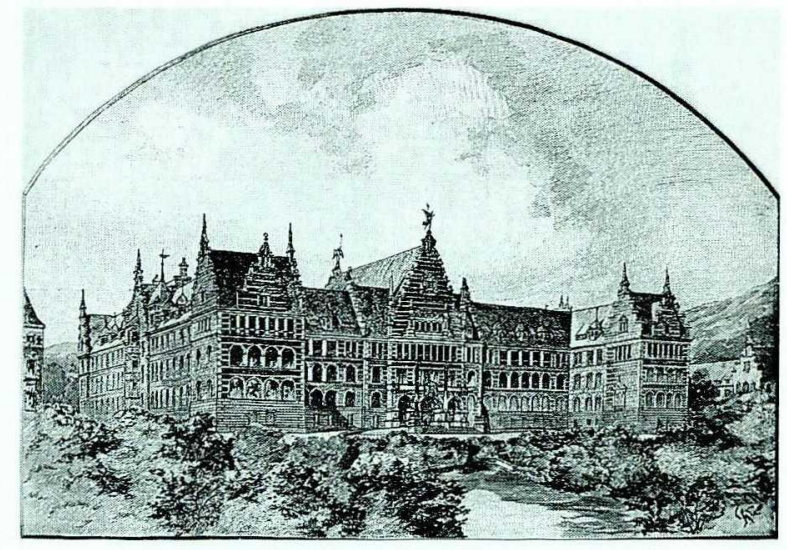

Fig. 3. Gdańsk, Technical University

Technische Hochschule Danzig),

project of Hermann Eggert and Georg Thür, 1898.

repr.: Zentralblatt der Bawerwaltung, 1899, p. 551.

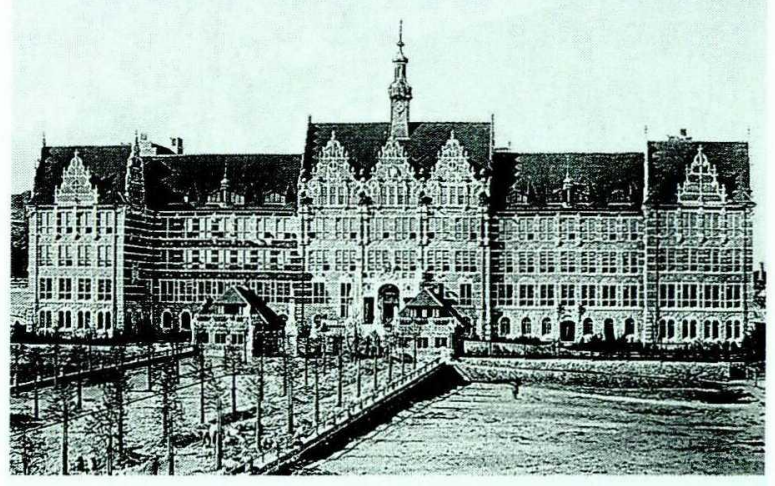

Fig. 4. Gdańsk, Technical University (Technische Hochschule Danzig), Albert Carsten, 1900-1904. repr.: Technische Hochschule in Danzig. Festschrift zur Eröffnung 6 Oktober 1906, Danzig 1904, after p. 8.

for all the complex buildings was made in Berlin; it was also in Berlin that the ministry of public works designed the first complex, with Hermann Eggert initially working on it, to be followed by Georg Thür (Fig. 3). Already in the first publications written among the Berlin circle on the planned university it was said that "in the architectural forms a reference to the sphere of

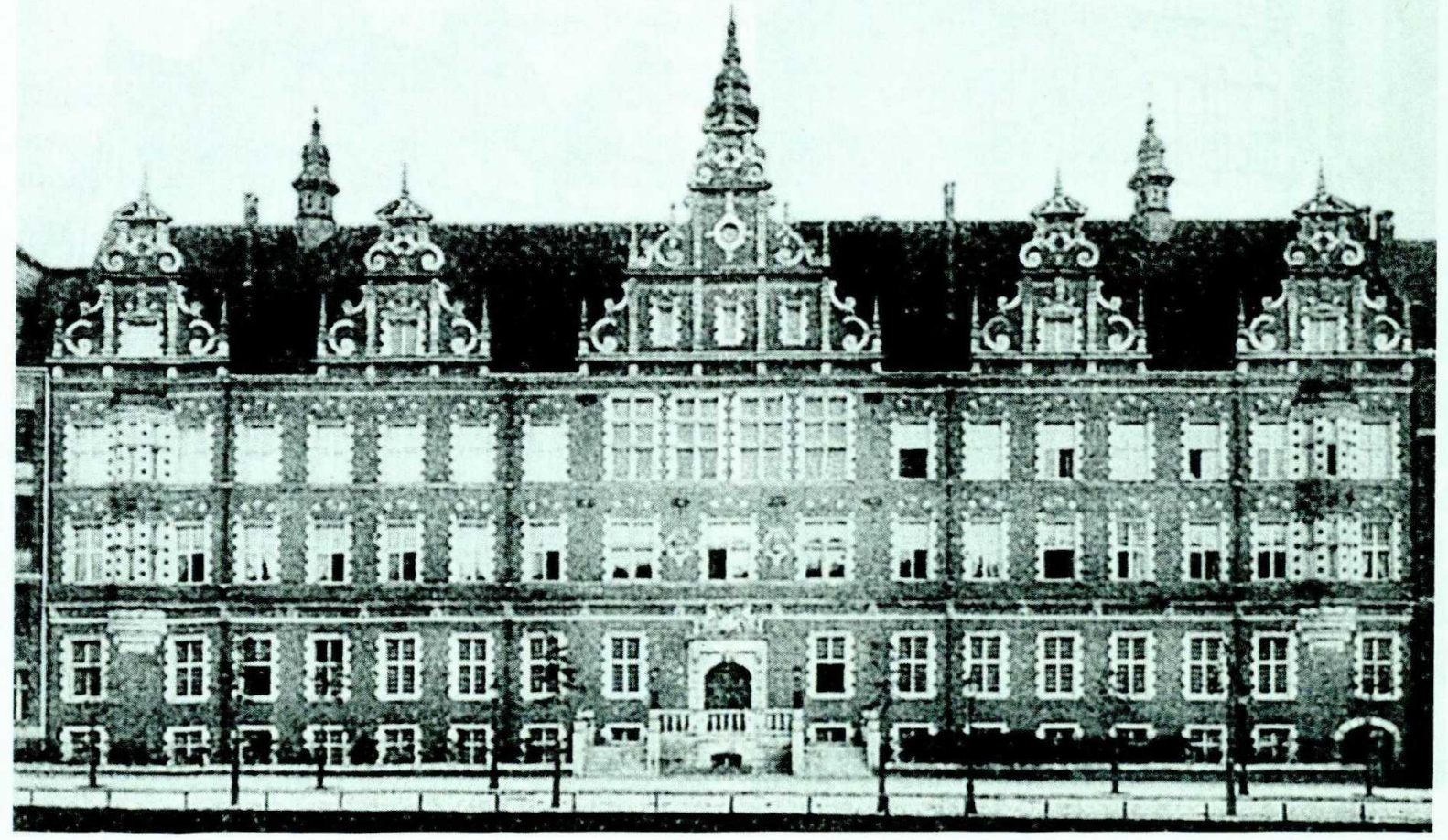

Fig. 5. Gdańsk, Edifice of the Insurance (Landesversicherungsanstalt), Curt Hempel, 1903-1905, repr.: Danzig und seine Bauten, Danzig 1908, p. 141 


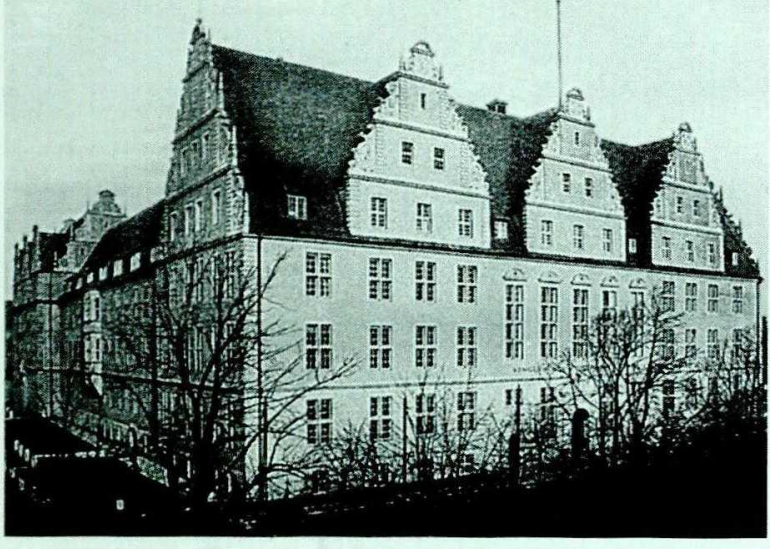

Fig. 6. Gdańsk, City Court

(Land-und Amtsgerichtsgebäude), arch. Saal, 1910,

Zeitschrift für Bawwesen, 1913, p. 209-210.

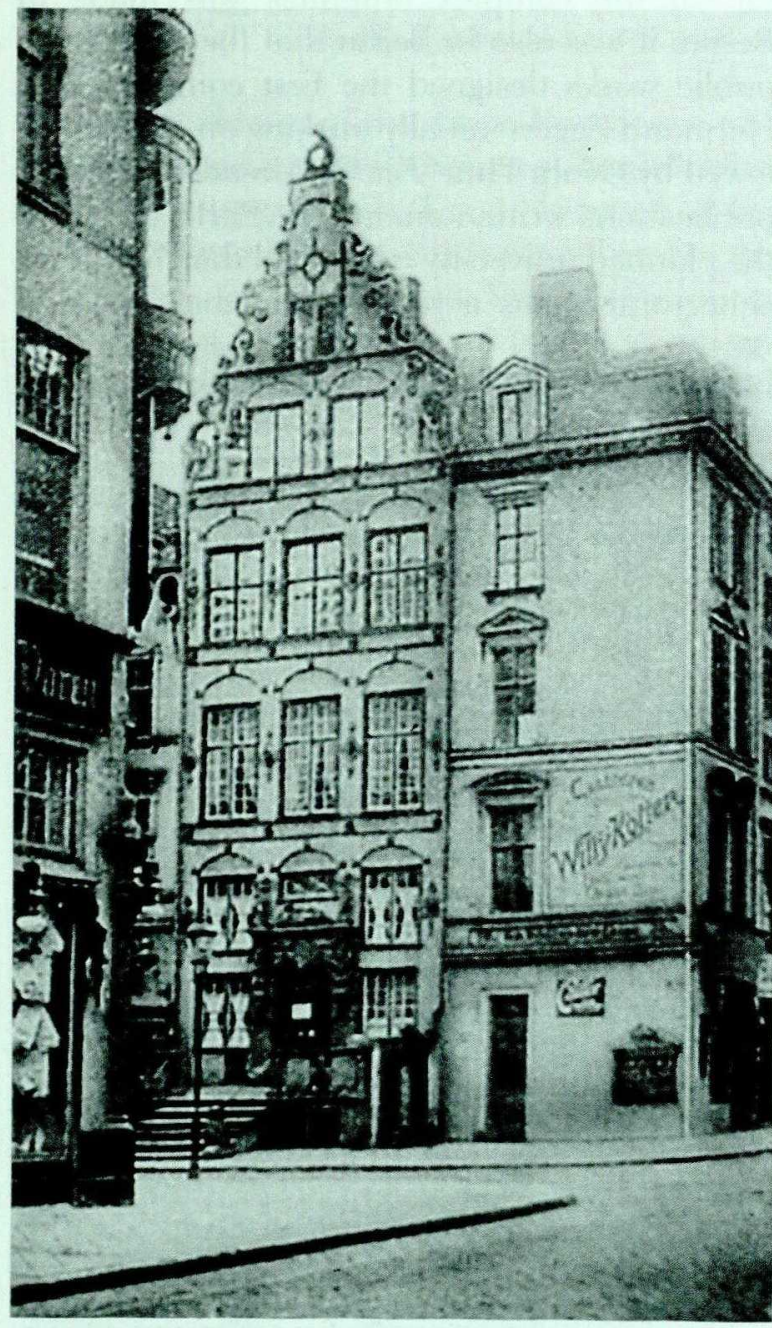

Fig. 8a. Gdańsk, Schlüter House in Jopengasse today Piwna Street), before restauration.

repr.: Zentralblatt der Bauverwaltung, 1913, p. 236.

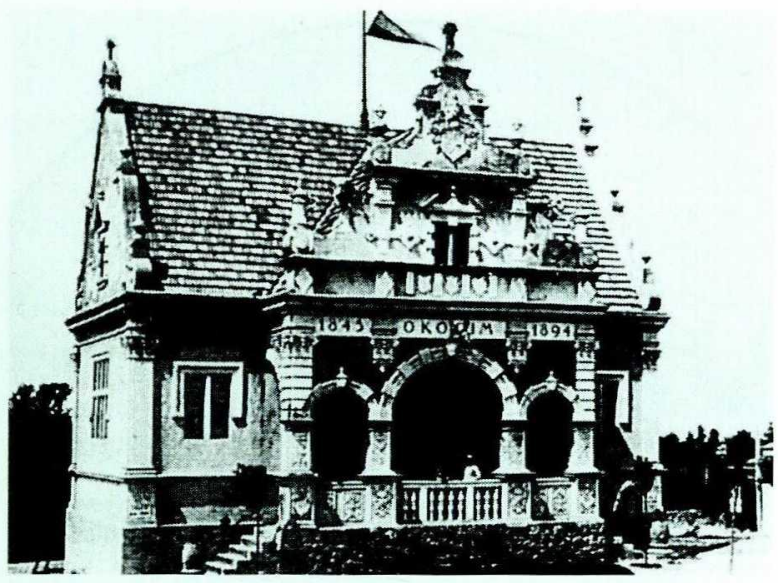

Fig. 7. Okocim, exhibition pavilion of the Okocim Brewery, 1894, Tomasz Pryliński.

repr.: Wystawa Powszechna Krajowa 1894 r. i sity produkcyjne w kraju, Lwów 1897, vol. 1, nr 1, p. 158.

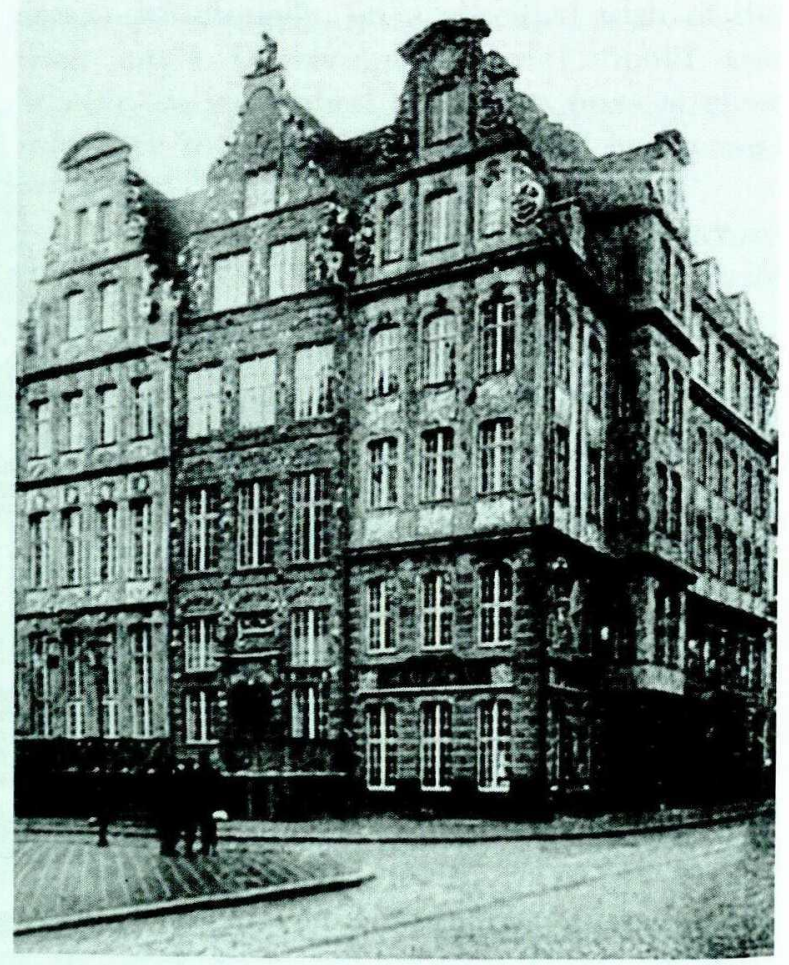

Fig. 8b. Gdańsk, Schlüter House in Jopengasse (today Piwna Street), after restauration of Carl Anton Meckel, 1911-1913. repr.: Zentralblatt der Bauverwaltung, 1913, p. 236. 


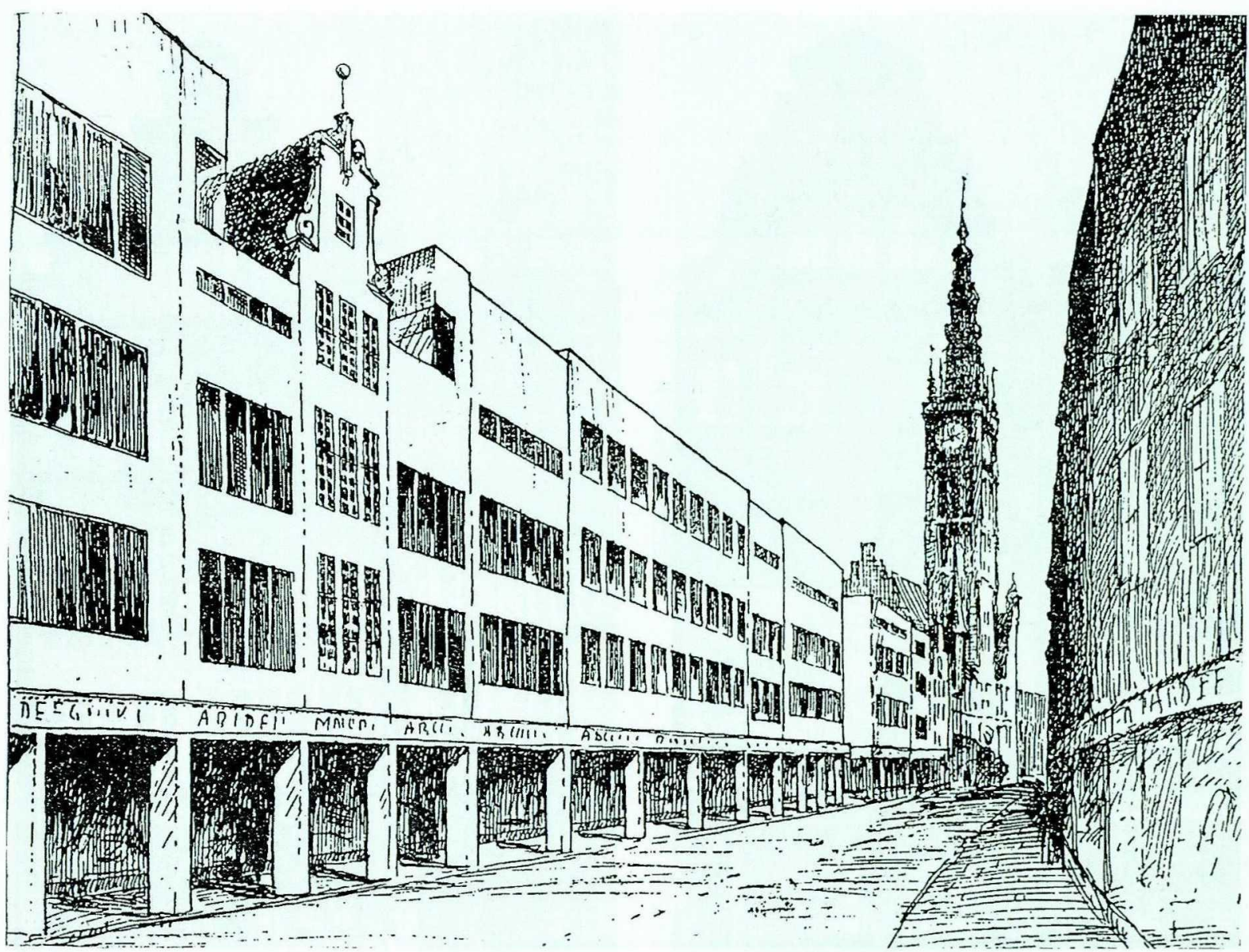

Fig. 9. Modern Houses, Langgasse in Gdańsk, draft project along the ideas of Martin Kiessling. repr.: Otto Kloeppel, Danzig am Scheidewege, Danzig 1928, p. 19

Danzig's old Renaissance buildings should be sought". ${ }^{10}$ In 1899, the designs were given a positive opinion by the Akademie der Bauwesen, yet on the Emperor's order: "auf Allerhöchste Anordnung", the initially designed forms apparently referring to Dutch Renaissance were replaced by "Alt-Danzinger Bauweise" forms, closer in character. ${ }^{11}$ The final implementation designs authored by Albert Carsten were, in fact, enriched with a much greater number of gables than Eggert and Thür had assumed (Fig. 4).

In the last years of the $19^{\text {th }}$ century and the first decade of the $20^{\text {th }}$ century some dozen NeoRenaissance public buildings were raised in Gdansk, this including the police headquarters, the edifice of the Insurance Landesversicherungsanstalt, Fig. 5), the Reich's Bank, the Town Archives and the Court (Land-und Amtsgerichtsgebäude, Fig. 6), as well as an impressive Railway Station, with a tower quoting almost literary the tower of the Town Hall. What is more, the success of the style spread over to tenement houses and villas, hotels, department stores, bank headquarters, and many others. In major public buildings only some few cases of references to a different style can be observed, each time this style being Neo-Gothic with additional clear reference to Gdansk buildings.

The new architecture of Gdansk in 18801910 was equally German and Gdansk in its stylistics, it allowed for both national and local identification, which was clearly read by the then German inhabitants of the city. This did not, however, remain equally obvious for the Poles as much as the local identification was clear also for them, the relations with the national German style were no longer so. This is testified not only by the writings of the period, starting from the reports on the expeditions of Polish architects to Gdansk, ${ }^{12}$ to the guide texts on the other extreme, ${ }^{13}$ but also the episodic as it might be, but meaningful at the same time use of the "Old 

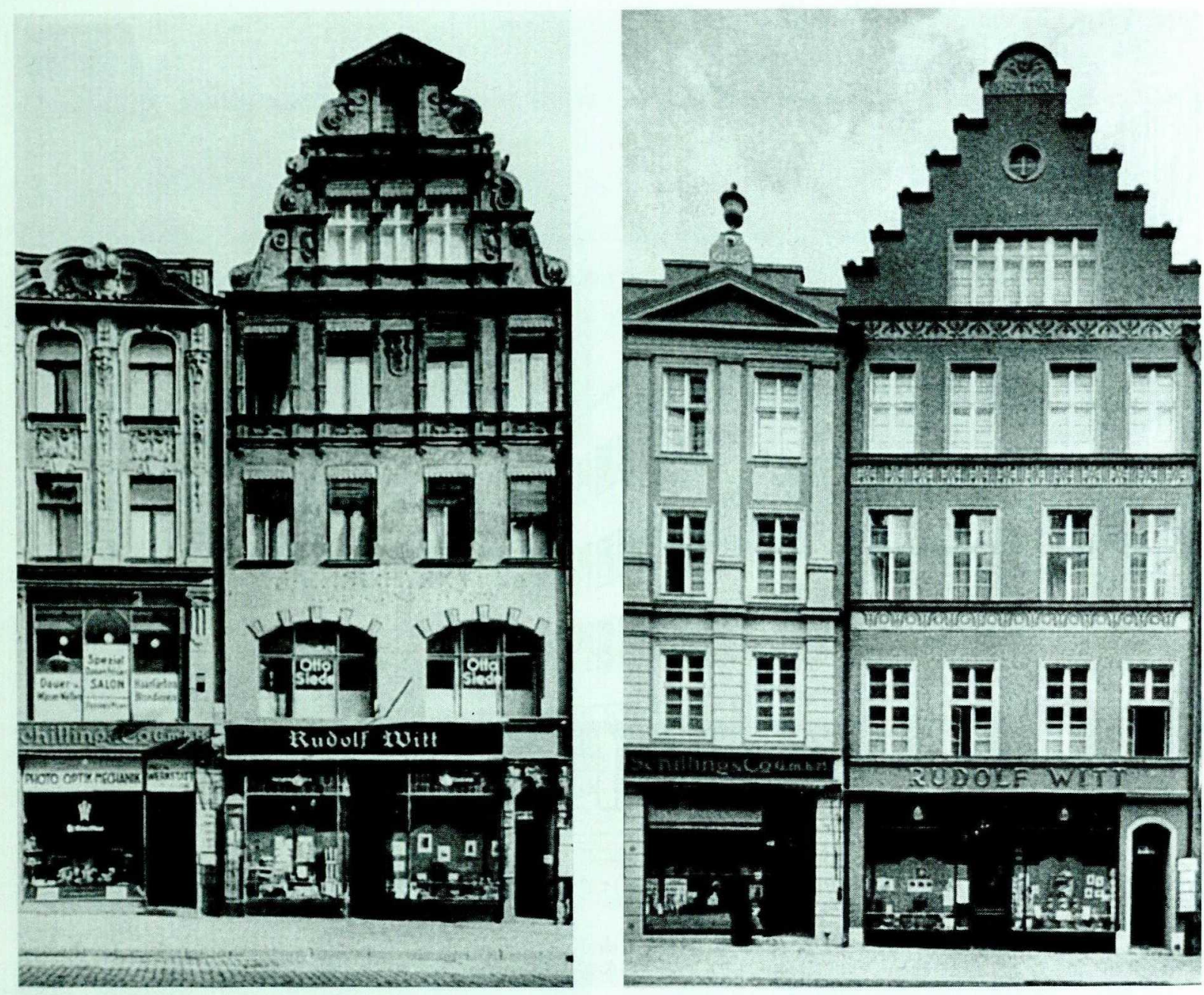

Fig. 10. Gdańsk, Houses, Langgasse 50 and 48/49, before and after renovation in 1938, arch. Felix Tiede, repr.: Erich Volmar, Danzigs Bawwerke und ihre Wiederherstellung. Ein Rechenschaftsbericht der Baudenkmalpflege, Danzig 1940, il. $30 / 31$.

Gdansk" style in the exhibition pavilion of the Okocim Brewery built in Lvov by the Cracow architect Tomas Pryliński in 1894 (Fig. 7). The use of the "Old Gdansk forms" was in the eyes of the commissioning entity meant to emphasize the long tradition of beer brewing in Okocim, as a matter of fact located in the south of Poland, in the then Galicia. ${ }^{14}$

The dominance of German Neo-Gothic in Gdansk architecture was in a way consolidated by establishing a strong centre of research into the old architecture of the city which was created at the Architecture Department at Gdansk Technical University in 1904. The architects who formed it became a conservative opposition versus any attempts to build differently, in a more modern manner, in compliance with German and European Avant-garde trends in architec- ture, while promoting conservative solutions. Meanwhile, the Gdansk milieu willingly accepted the influence of Heimatschutzbewegung, which was soon to be seen in the architecture of villa quarters, first of all in Langfuhr and the estates in the style of "garden-cities", such as e.g. the complex of a clerks' cooperative in Neuschottland.

The focus on the past and the values of old architecture yielded even before the outbreak of World War I the first attempts to restore the original homogeneous character to the old quarter of the city. In practice, this meant the rejection of the buildings from the first half of the $19^{\text {th }}$ century, yet at the same time the first voices of criticism of late Historicism could be heard. In 1910 , on the initiative of the private real-estate's owners a competition was held to alter two houses adjacent to the Baroque so-called Schlüter 


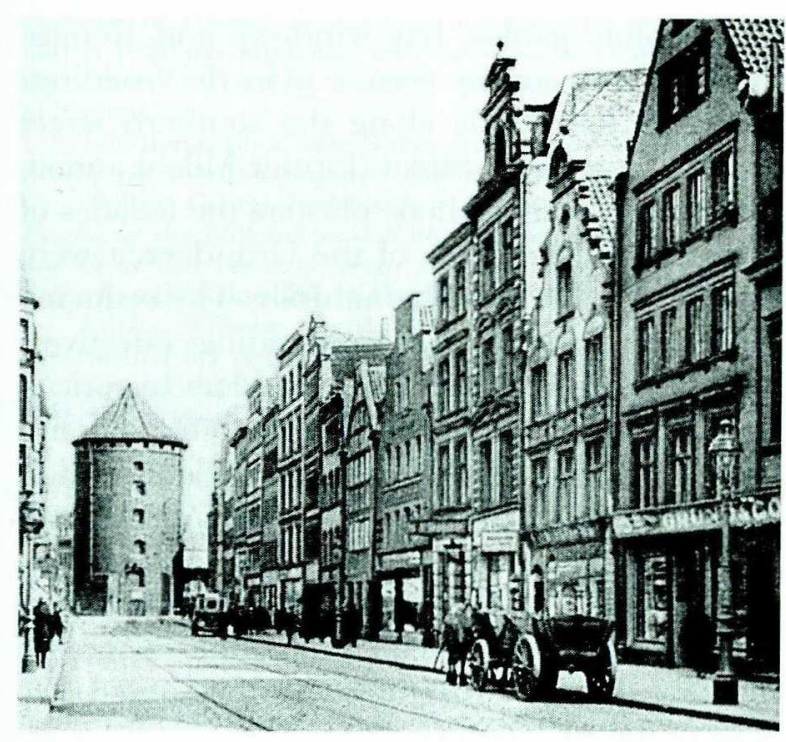

Fig. 1 Ka. Gdańsk, Milchkannegasse (today Staggiewna), Fot. ca. 1930, Neg. in Archiv ISPAN

House in Jopengasse (today's Piwna Street). The winning design was authored by Carl Anton Meckel and it assumed the stylistic adjustment of the buildings to be altered both to the abovementioned houses and buildings along the whole street. In effect, a pastiche on Baroque architecture was achieved: formally, very close to the Schlüter House, yet featuring shapes that those houses most probably had never had (Fig. 8a-b).

In the interwar-period, during the existence of the Free City of Danzig, architects affiliated with the Architecture Department of the Technical University continued to have a decisive voice on the shape of Gdansk architecture. They effectively hampered any attempts to raise any Avantgarde designs in the historical city centre, which Martin Kiessling, holding the office of Gdansk's city architect in 1927-1929 verified personally (Fig. 9). He had succeeded to have two schools raised according to his designs in some other districts of Gdansk, yet the idea to introduce any modern urban solutions in the strict centre of the city was strongly criticised, mainly by Otto Kloeppel and these projects, in fact, remained unaccomplished. ${ }^{15}$

After the National Socialist Party had won power in 1933, in Gdansk a broad campaign to restore the monumental centre of the city was started. Within 6 years a great effort was put to restore the old aspect to the city by removing shop windows pierced at the turn of the $19^{\text {th }}$ cen-

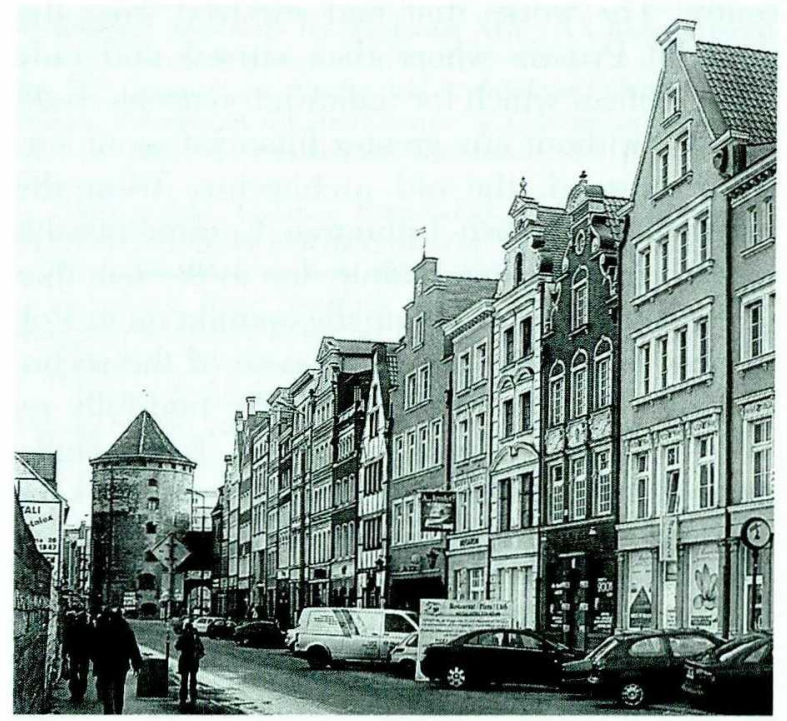

Fig. I1b. Gdanísk, Stagiewna (former Milchkannegasse), after reconstructions 1997, fot. 2007, M. Omilanowska

tury, by reducing the number of aggressive advertising, but first of all by altering houses that "did not match" the historical architecture in the spirit of the architecture of the old Gdansk. ${ }^{16}$ It was first of all buildings from the $19^{\text {th }}$ and the beginning of the $20^{\text {th }}$ century that fell victim to those alterations, for their Neo-Renaissance forms characteristic of late Historicism not longer matched the concept of the true Old Gdansk architecture of the generation deciding on the new shape of the centre of Gdansk in the 1930s. The accomplished result proved to create a very homogeneous whole, specially as any remains reminding of the fact that the city had once belonged to Poland and which had survived the Prussian times were as a matter of fact eliminated (Fig. 10).

The year 1945 resulted in an almost complete annihilation of the historical centre of Gdansk, whereas in the aftermath of the decision of the great powers the city was to be on the territory of the Polish People's Republic. Its former inhabitants who had not managed to evacuate before the war front arrived, were displaced, their homes to be populated by the Poles, mainly coming from the eastern territories of Poland incorporated into the Soviet Union. A new stage in the history of the city started in which political and social needs related mainly to the need to tame space and gain new identification motivated the decision to rebuild the destroyed city 
centre. The works that had survived from the times of Prussia where then cursed and only those edifices which for utilitarian reasons could be used without any greater financial input survived. Instead, the old architecture from the times of the Polish-Lithuania Commonwealth was worth restoring, mainly due to the fact that in the course of the debate the opinion on its Polishness prevailed. ${ }^{17}$ In the course of the reconstruction all the city "icons" were faithfully restored: the City Gates, churches, Town Halls, Artus Court, and the Court of St. George, yet the residential architecture was rebuilt in order to satisfy the needs of an already new working estate, hiding behind the "Gdansk" gabled narrow facades ordinary apartment blocks grouped around internal courtyards, once very densely built up. ${ }^{18}$ On the very occasion an attempt to "Polonize" or rather "de-Germanize" the reconstructed buildings was made to consciously manipulate iconographic motifs of the facade decoration, specially along the stately route along Długa and Długi Targ Streets. ${ }^{19}$ The complex of the reconstructed old centre of the city was to become the symbol of Poland's eternal presence on the Baltic (Fig. 11a-b).

An amazing newest chapter in the history of the reception of Gdansk architecture and searching for the places of local identification began in the 1990s. Apparently, among the circles of quite an influential group of Gdansk intellectuals a concept was born to reconstruct the works of Neo-Renaissance architecture from the Wilhelm times, as the latter was regarded to be an excellent example of the Gdanśk genius loci and a signpost for modern architects searching for a new expression for Gdansk architecture. ${ }^{20}$ Paradoxically, in the eyes of some contemporary Gdansk residents the German architecture, the Gründerzeit, turned out to be an attractive alternative to some contemporary designs. The result of a such-conceived policy of cherishing the local genius loci and revealed in the brick-stone eleva- tions, volute gables, bay windows and Renaissance turetts, can be seen, e.g. in the buildings raised in the 1990s along the southern street front of Stagiewna Street (former Milchkannengasse), where in synthetic plasters the facades of houses from the times of the Gründerzeit were recreated not extremely faithfully. The seducing picturesque quality of those buildings effectively overcomes in many Polish beholders historical, and until recently negative, connotations. Paradoxically, this possibility of local identification with the architecture of the German times turned out to be so attractive, as it provides an opportunity to create yet another Gdansk myth on the city's tolerance, openness, multiethnic character. meaning features desirable for the united Europe of the $21^{\text {st }}$ century.

Actually, the analysing of Gdansk architectural legacy in the national categories of the Polish or German qualities has created a number of myths, fabricating this or that myth for the purpose of current political needs. Over the last two centuries authors writing about Gdansk architecture have developed a whole range of strategies of appropriation supported by a strong awareness of a multi-century-lasting Polish-German national conflict. And the easiest way out always turned out to be the reference to the local dimension of things, the mythology of an always free and independent Gdansk, overwhelmed by that genius loci which allowed it to maintain cultural continuity despite a complicated political history.

The Renaissance architecture of Gdansk, interpreted by scholars, architects, and the $19^{\text {th }}$-century Prussian residents of Gdansk served as grounds for creating the architecture of Historicism in its national style, yet of local connotation, which apparently 100 years later has been regarded by the Poles living in the city as a manifestation of the genius loci and has been raised to the status of a two-aspect model: of local identification and an over-national tolerance at the same time.

\section{NOTES}

${ }^{1}$ Let me just remind you the very basic historical facts which have given the shape to the city. The settlement recorded for the first time in 997 developed as the capital of a Slav Pomeranian Duchy, and around mid-13 $3^{\text {th }}$ century it was given town privileges. Captured by the Teutonic Order in
1308, in 1361 Gdansk was incorporated into the activity of the Hanseatic League. In 1466, after the 13-years' War Cdansk separated from the Teutonic state and incorporated into the Polish-Lithuanian Commonwealth gaining, however, an exceptional and very privileged position. After the second 1793 
partition of Poland, Gdansk was incorporated into Prussia. and in 1920 in compliance with the Versaille Treaty it gained the status of a Free City under the protectorate of the League of Nations.

2 I do not mention here earlier publications of topographicdescriptive character prepared mainly among the Gdansk circle.

"Möller, Georg: Beiträge zur Kenniniss der deutschen Baukunst des Mittelalters enthaltend eine Reihe von Werken aus dem Sten bis zum 16ten Jahrhundert Denkmäler der deutschen Baukunst. Bd.1), Darmstandt 1821.

+ Lübke, Wilhelm, Geschichte der deutschen Renaissance (Geschichter der Baukunst, Bd 5), Stuttgart 1873.

"Kruszyniski, Tadeusz: Stary Gdańsk i historya jego sztuki The Old Gdansk and the History of its Art). Wieliczka 1913.

${ }^{6}$ Friedrich, Jacek: Netherlandism of Early Modern Gdańsk Art in the Eyes of Polish Researchers before 1945 in: Netherlandish Artists in Gdanisk in the Time of Iland Vredeman de Vries, Material from the Conference organized by Museum of the History of the City of Gdańsk and Weserrenaissance-Museum Schloß Brake Lemgo, Gdańsk-Lemgo 2006, pp. 23-29.

? Omilanowska, Małgorzata: Architektura Gdariska lat 1871-1914 (Architecture of Gdansk of 1871-1914): Gdansk or (rather) German? In: Mecenal a artyslyczne oblicze miast. Materiaty LVI Ogólnopolskiej sesji Stowarzyszenia /listoryków Sztuki Artistic Patronage versus the Artistic Facel of a Town. Materials of the Symposium of the Association of Art Mistorians), Kraków 2006, ed. Darius Nowicki, Kraków 2008, pp. 169-184.

${ }^{8}$ Pospieszny, Kazimierz: Neorenaissance-Architektur in Danzig (Gdańsk) in: Renaiisance der Renaissance, ed. Georg Urich Großmann, (Schriften des Weserrenaissance-Museums Schloß Brake, 8), 1995, pp. 133-1+2.

"Menneckes, Ralf: Die Renaissance der deulschen Renaissance, Petersberg 2005

${ }^{10}$ Der Plan einer neuen Technischen Hochschule in Danzig. Zentralblatt der Bawerwaltung, 19 (1899), p. 124.

${ }^{11}$ Die Neubauten für die Technischen Hochschule in Danzig. Zentralblatt der Bawerwaltung; 22 (1902), p. 454.
${ }^{12}$ Lewicki, Jakub: Recepcja architektury gdańskiej w środowisku lwowskim na przelomie XIX i XX wieku (Reception of Gdansk Architecture in the Lvov Circles at the Turn of the $19^{\text {th }}$ Century), in: Studia nad archilekturq Gdanska $i$ Pomorza, Studies in the Architecture of Gdansk and Pomerania), ed. Andrzej Grzybkowski, Warszawa 2004, pp. 215-226 (here p. 223).

${ }^{13}$ Kruszyński, Tadeusz: Przewodnik po Gdańsku i okolicy (A Guide to Gdansk and its Environs), Warszawa 1914, p. 11.

${ }^{1+}$ Lewicki 2004 (see note 12 ), p. 220.

1.5 Pusback, Birte: Stadt als Heimat. Die Danzinger Denkmalpflege zwischen 1933 und 1939, Köln 2006, pp. 203-209.

${ }_{10}$ Pusback 2006 (see note 15), pp. 192-203.

17 Friedrich, Jacek: Diskussion über den Wiederaufbau von Danzig in den Jahren 1945-1948, Mare Balticum 1999, Ostsee-Akademie Lübeck-Travemünde [2000], pp. 24-34.

${ }^{18}$ Friedrich, Jacek: Główne założenia odbudowy historycznego Gdańska (Main Assumptions of the Reconstruction of Historical Gdansk), in: Kunslgeschichte und Denkmalpflege. IV. Tagung des Arbeitskreises deutscher und polnischer Kunsthistoriker und Denkmalpfleger. Torun 2.-6. Oklober 1997, ed. Woźniak Michat, Toruń 2002, pp. 213-222; idem: Kontinuität und Innovation beim Wiederaufbau Danzigs, in: Architektur und Städlebau im Südlichen Ostseeraum zwischen 1936 und 1950, ed. B. Lichtnau, Berlin 2002, pp. 169-174

${ }^{19}$ Friedrich. Jacek: Wystrój dekoracyjny Drogi Królewskiej w Gdańsku w latach 1953-1955 (Decoration Elements of the Royal Route in Gdansk in 1953-1955), Gdańskie Studia Muzealne (Gdansk Museum Studies), 6 (1995) [2000], pp. 111133.

20 Friedrich, Jacek: Problem "gdańskosici" w architektonicznych upodobaniach wspólczesnych gdańszczan (The Issue of the "Gdansk Character" in the Architectural Predilections of Contemporary Gdansk Residents), in: Gust gdański. Materiaty z sympozjum 23-2+ października 2002 Gdansk Taste. Materials from the Conference October 23-2+, 2002), ed. Bronislaw Dejna and Jakub Szczepański, Cdańsk 2004, pp. 82-98. 